\title{
Reproductive biology of the palm borer, Paysandisia archon (Lepidoptera: Castniidae)
}

\author{
Roxane DELLE-VEDOVE ${ }^{1,2}$, LaURence BEAUdOIN-OLLIVIER ${ }^{1}$, Martine HOSSAERT-MCKEY ${ }^{2}$ \\ and BRIGITTE FRÉROT ${ }^{3}$
}

${ }^{1}$ CIRAD, UPR Bioagresseurs, Avenue Agropolis F-34398 Montpellier, France; e-mail: roxanedv@hotmail.fr

${ }^{2}$ Centre d'Ecologie Fonctionnelle et Evolutive (CEFE), UMR CNRS 5175, 1919 route de Mende, 34293 Montpellier cedex 5, France

${ }^{3}$ INRA Versailles, UMR PISC 1272, Route de St Cyr 78026 Versailles Cedex, France

Key words. Lepidoptera, Castniidae, Paysandisia archon, diel periodicity, pheromone production, polyandry, sexual maturity

\begin{abstract}
Paysandisia archon (Burmeister, 1980) (Lepidoptera: Castniidae) is an accidentally introduced pest that damages palm trees in the northern Mediterranean area. To our knowledge, there are no experimental studies on its mating behaviour, and little is known about its biology and ecology. In the present study, we used outdoor experiments to investigate several characteristics of the reproductive behaviour of $P$. archon: sexual maturity, diel periodicity of mating, occurrence of polyandry and delay between mating and laying eggs. The results indicate that $73 \%$ of the individuals studied were sexually mature three hours after adult emergence. Mating peaked between 14:00 $\mathrm{h}$ and 15:00 $\mathrm{h}$ and $87 \%$ of the females were fertilized and started laying eggs $1.25( \pm 1.14)$ days after mating. Females were generally monandrous, but nevertheless remained attractive after mating. The results of this study provide the necessary background knowledge for studying several aspects of $P$. archon reproductive biology, in particular oviposition, sex pheromones and their role in mediating mating behaviour in this pest. These results are the first step in developing tools for monitoring populations of this pest.
\end{abstract}

\section{INTRODUCTION}

The palm borer Paysandisia archon (Burmeister, 1980) (Lepidoptera: Castniidae) was recently introduced into Europe, and is the sole European representative of the mostly Neotropical family Castniidae. Larvae of this species feed on numerous species of palms (Arecaceae). This species native of South America, primarily Argentina and Uruguay (Lamas, 1995; Miller, 1995), was introduced into the Mediterranean area in the late 1990's with the importation of palm trees (Sarto I Monteys \& Aguilar, 2005). Paysandisia archon has since rapidly extended its range in the whole of the northern Mediterranean region, causing severe damage to palm trees and becoming a major pest of both native and introduced species (Dresher \& Jaubert, 2003; Sarto I Monteys \& Aguilar, 2005). Currently, the damage it causes to ornamental palms is of greatest concern, but the only species of palm native to the Mediterranean, Chamaerops humilis (L.) (Arecales: Arecaceae), is also attacked. Moreover, there are concerns that $P$. archon could become a major economical threat in the Maghreb, as date palm, Phoenix dactylifera (L.) (Arecales: Arecaceae) is also a potential host (Dresher \& Jaubert, 2003). Thus, developing methods for monitoring $P$. archon populations is important not only in urban areas but also in countries of the Maghreb where this species is a major threat to an important food crop.

In its native area, $P$. archon is not a pest (Sarto I Monteys \& Aguilar, 2005). Therefore, there is very little information on the reproductive biology of this day-flying moth. Recent studies in Europe report a long-lasting larval stage (10.5 to 18.5 months; Sarto I Monteys \& Aguilar, 2005) but there is no information on how to rear this species. Imagos are observed on sunny days from May to September, but they do not feed (Sarto I Monteys \& Aguilar, 2005) and for finding a mate may rely on pheromones emitted by the females (Ollivier \& Frérot, 2006). Pheromone-based control methods (mating disruption, phero- mone traps) are widely and effectively used in the integrated management of a number of pest moths (Cardé \& Minks, 1995), but for their use against $P$. archon a basic knowledge of this species reproductive biology is required.

Pheromone identification involved preliminary studies on female physiology, especially the time needed for ovary maturation and diel periodicity in mating behaviour. Indeed, in most Lepidoptera, mating activity is regulated by females releasing a pheromone during specific calling windows (Callahan, 1958; Shorey \& Gaston, 1965; Sower et al., 1971). The beginning of calling generally coincides with maximum production of the pheromone by females in Lepidoptera (Fatzinger, 1973; Coffelt et al., 1978; Raina et al., 1986; review in Delisle \& Royer, 1994) and is the first step in reproductive behaviour. By assessing the rhythms in essential reproductive acts, such as first mating, mating frequency and egg laying we aim to provide the necessary basic information on pheromone production and associated behaviour needed for monitoring populations of this introduced pest.

\section{MATERIAL AND METHODS}

\section{Insects}

Insects used in our experiments were collected as last instar larvae or pupae from infested palm trees that were felled in and around Montpellier (France, $43.37^{\circ} \mathrm{N}, 3.52^{\circ} \mathrm{E}$ ) between January and July 2009. After collection, larvae were placed in individual circular plastic boxes $(80 \varnothing \times 50 \mathrm{~mm})$ with organic matter collected from damaged palms and kept in the dark in a warehouse under natural temperature conditions (ranging from $5^{\circ} \mathrm{C}$ to $30^{\circ} \mathrm{C}$ ) until pupation. From April to August the larvae pupated and the pupae were kept in a laboratory at $25^{\circ} \mathrm{C}$ under a natural photoperiod. Each day, the sex of emerging moths was determined. Males and females were kept in separate rooms to avoid exposing them to intersexual odours. Moths were placed into 
fine mesh cages $30.5 \times 30.5 \times 30.5 \mathrm{~cm}$ (www.livemonarch.com) kept under the same conditions as cited above. Thirty three percent of the collected larvae or pupae $(n=236)$ emerged as adults between May and August. All the experiments were conducted under outdoor conditions on sunny days with insects enclosed in fine mesh cages $(60 \times 60 \times 91 \mathrm{~cm})$. Experiments were performed between 15 June and 15 July, when the natural photophase lasted from $06: 30 \mathrm{~h}$ to $21: 30 \mathrm{~h}$ (Fig. 1).

\section{Plants}

A single five year old $C$. humilis (40-60 cm height) obtained from a commercial supplier and grown under natural conditions in Montpellier was placed into each cage. Most of the plants had never set fruit and therefore were not mature.

\section{Sexual maturity and diel periodicity in mating}

Fifteen pairs of newly emerged males and females of $P$. archon were each placed in a cage shortly after wing extension. The moths were observed continuously each day from 08:00 h to $18: 00 \mathrm{~h}$ until they mated. Day and hour of first mating were recorded.

\section{Diel periodicity in flight activity}

Sixteen individuals ( $\mathrm{n}=8$ males and 8 females) from the 15 previously mated pairs were observed continuously from 08:00 $\mathrm{h}$ to $18: 00 \mathrm{~h}$ for eight consecutive days. On four of the eight days observations were continued until the beginning of the scotophase (at 22:30 h). The first bout of activity lasting for more than five minutes was taken as the time of onset of activity and was considered to have ended if there was a "pause" in flight activity of more than $60 \mathrm{~min}$.

\section{Female egg laying and fertility of eggs}

To determine the time interval between mating and egg laying the females of each of the above 15 mated pairs were kept individually in a cage until their death. Eggs were collected at the end of each day and kept individually in boxes until hatching to confirm that they were fertilized. The boxes were kept in the dark (to reproduce conditions inside a palm stem) and at $25^{\circ} \mathrm{C}$. Eggs were checked for hatching each morning until at least one hatched or, for twenty-one days, which is the maximum time required for hatching in $P$. archon (Dresher \& Jaubert, 2003; Sarto I Monteys \& Aguilar, 2005). Females were assessed as having been inseminated if at least one egg hatched.

\section{Polyandry}

To determine whether females are monandrous or polyandrous, two groups of mated females, not used in previous experiments, were tested. The first group included females that had not yet laid any eggs $(\mathrm{n}=12)$ and the second females that had laid their first eggs two days earlier $(n=14)$. In both groups the females were from one to six days old and each was provided with a new virgin male from two to six days old. Pairs were observed in outdoor individual cages; copulation attempts and matings were recorded from the beginning of the mating activity period (11:00 h; see Results section) for two hours. This time is the maximum time elapsed before mating of non emerging (one to six days old) virgin moths $(90 \%$ of $n=40$ pairs; R. Delle-Vedove, unpubl. data). In addition, to assess if females would re-mate with the same male, a third group of seven mated pairs were kept together in individual cages after their first mating (previous experiments on sexual maturity) and until a female laid an egg. These seven pairs were observed continuously from $08: 00 \mathrm{~h}$ to $18: 00 \mathrm{~h}$ and copulation and attempted mating recorded.

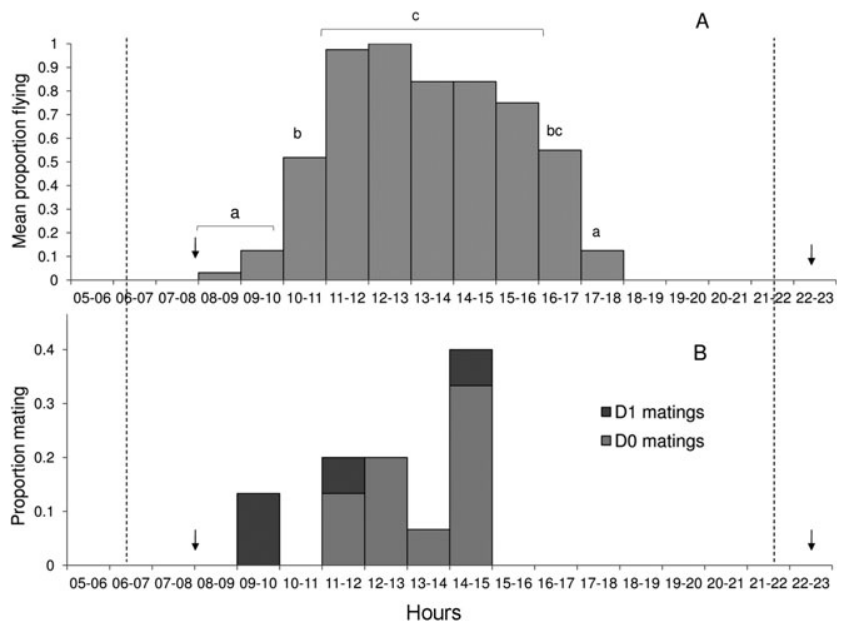

Fig. 1. Flight (A) and mating activity (B) of $P$. archon recorded during the day and into the evening. In (A), as no differences were found between the activity periods of males and females (Chi-square test; $\chi^{2}=15.20, P=0.06$ ), data were pooled for all individuals $(\mathrm{n}=16)$. Black arrows indicate the beginning of the observations. Dotted lines indicate beginning and end of the photophase during the observations (June and early July). Letters indicate significant differences between the activities recorded at different times (Chi-square test; $P<0.05$ ). Braces indicate consecutive hourly records with the same letter. D0 - pairs that mated on the day of emergence; D1 - those that mated one day after they emerged.

\section{Statistical analysis}

A chi-squared test was used to analyze the significance of differences in frequencies of females re-mating and of males attempting copulation, in the three polyandry experiments. The same type of test was used to test differences in mean frequencies of active individuals and the number that mated at different times during the observation period. When the number of individuals was less than five, observations were pooled for to successive hour-long periods. Significance of differences between males and females in the interval between emergence and mating was analyzed using a Mann-Whitney test. All analyses were performed using R 2.12.0.

\section{RESULTS}

\section{Diurnal flight activity}

$P$. archon flew between 08:47 h and 17:42 h. Mean proportions of individuals flying recorded each hour differed significantly (Chi-square test; $\chi^{2}=211, P<0.001$ ) with a significant peak between 11:00 h and 16:00 h (Fig. 1A). None flew in the evening, i.e., between 18:00 and 22:30 h (Fig. 1A).

\section{Time to sexual maturity and diurnal mating activity}

Of the 15 pairs observed $100 \%$ copulated, $73 \%$ on the day they emerged ("D0 matings") and the remaining $27 \%$ on the second day ("D1 matings"). Mating lasted a mean of $35.00 \pm$ 9.90 min and termination of mating was always initiated by the male, walking or flying away from the female.

The mean period between emergence and first mating was $168 \pm 41 \mathrm{~min}$ and $183 \pm 63 \mathrm{~min}$ (mean $\pm \mathrm{SE}$ ) for males and females, respectively; the two sexes did not significantly differ in this respect (Mann-Whitney: $\mathrm{U}=44, P=0.677$ ). All the D0 matings occurred between 11:00 and 15:00 h and peaked at 14:00-15:00 h (Fig. 1B) while D1 matings, occurred between 09:30 $\mathrm{h}$ and 15:00 $\mathrm{h}$ (Fig. 1B). However, overall there are no 
TABLE 1. Proportions of $P$. archon males that attempted to copulate with mated females, and of females that were polyandrous, in three experiments designed to test for polyandry: (i) with the same male (previously mated male) or, with a different 2 to 6 day old virgin male (virgin male) (ii) before and (iii) after the female laid her first egg. E.L. = Egg Laying.

\begin{tabular}{ccccccc}
\hline & \multicolumn{2}{c}{ Previously mated male } & & \multicolumn{2}{c}{ Virgin male } & \multirow{2}{*}{$\chi^{2} ; P$} \\
\cline { 2 - 2 } & Before E.L & & Before E.L. & After E.L. & \\
\hline$N$ & 7 & 12 & 14 & \\
Proportion of males attempting copulation & 0.86 & & 0.67 & 0.79 & $\chi^{2}=1.55 ; P=0.460$ \\
Proportion of females that were polyandrous & 0.14 & & 0.08 & 0.00 & $\chi^{2}=1.84 ; P=0.398$ \\
\hline
\end{tabular}

significant differences in the timing of D0 and D1 matings (Chisquare test; $\left.\chi^{2}=0.4, P=0.819\right)$

\section{Female egg laying and fertility of eggs}

In the case of three of the 15 females it rained for several days after they mated, which inhibited their activity, so the results for these females were not included in the analysis. The mean period between mating and first egg laying for the remaining 12 females was $1.25 \pm 1.14 \mathrm{~d}$ (mean $\pm \mathrm{SE}$ ) and ranged from 0 to 4 days. Females lived for a mean of $5.30 \pm 2.06$ days after laying their first egg, during which they laid eggs each day. Two of the 12 mated females laid no fertile eggs.

\section{Polyandry}

Of the 33 females tested in the three experiments, only two $(6 \%)$ mated twice. One mated with the same male ("previously mated male"; Table 1) and the other with a different, virgin male (Table 1). Both re-mated before laying their first eggs. In all experiments males attempted to copulate with females whether they had mated previously or not (Table 1).

\section{DISCUSSION AND CONCLUSIONS}

Our results confirm that $P$. archon is a diurnal moth with a peak in flight activity during the sunny hours of the day, between 11:00 $\mathrm{h}$ and 16:00 h, during which emerging moths were also sexually active. We found that in $P$. archon, $73 \%$ of the individuals were sexually mature and mated within three hours of emerging. In Lepidoptera, periods of mating activity closely associated with pheromone production follow specific diel periodicities. For example, in Dioryctria abietella (Denis and Schieffermüller) (Lepidoptera: Pyralidae), the maximum quantity of pheromone in abdominal tips occurs nine hours after the onset of the scotophase, a time at which calling, locomotion and mating also peak (Fatzinger \& Asher, 1971; Fatzinger, 1973). In addition, in many moths, the maximal pheromone titer in female glands is found at the onset of peak calling activity (Shorey \& Gaston, 1965; Fatzinger, 1973; Pope et al., 1982; Raina et al., 1986; Delisle \& Royer, 1994). In some species, such as Helicoverpa zea (Boddie) (Lepidoptera: Noctuidae), pheromone titers increase up to the onset of calling activity (Raina et al., 1991), whereas in other moths, such as Trichoplusia ni (Hübner) (Noctuidae), pheromone production is continuous and a high titer is maintained in the gland until the beginning of calling activity (Sower et al., 1971; Hunt \& Haynes, 1990). In this context, the period of mating activity and particularly the onset of it, three hours after emergence, should be considered as the best time for collecting pheromone from emerging females of $P$. archon. Sexual activity was recorded mainly between 11:00 $\mathrm{h}$ and 15:00 $\mathrm{h}$ and studies on reproductive behaviour should focus on this period. Nevertheless, daily activity rhythms in insects may be influenced by many factors, particularly temperature and photoperiod (Danilevsky et al., 1970, Sower et al., 1971). During the flight season of P. archon, which is from May to September, photoperiod and temperature vary. Our experiments were performed at the beginning of the flight season and on sunny days; it can be expected that daily rhythms of mating and flight activity will be different on overcast days or later in the flight season.

Mating occurred only on the second day in $27 \%$ of the pairs, which may indicate that some females reach sexual maturity later than others (Turgeon \& McNeil, 1982; Gemeno \& Haynes, 2000 ) and, while immature, may have lower titers of pheromone in their glands (Cusson \& McNeil, 1989). Moreover, in $P$. archon, some of the females mated on D1 earlier than others, which is recorded for other Lepidoptera in which it is suggested that the older females start calling earlier in order to increase their probability of mating (Delisle \& Royer, 1994). There was no significant difference in the time at which the females mated on D0 and D1, but this may be due to the small sample size. Future studies on reproductive behaviour and pheromone production should take female age and time of mating into consideration.

Only two (6\%) of the 33 females tested mated more than once and always before ovipositing, which indicates that $P$. archon females are generally monandrous. A similar pattern is reported in Lymantria dispar (L.) (Lymantriidae). When this generally monandrous moth is abundant, $10-30 \%$ of the females mate more than once (Proshold \& Bernon, 1994) because the sperm from the first mating does not reach the spermatheca (Giebultowicz et al., 1991). In our study, the female that mated twice with the same male was infertile, suggesting this may be due to the quality of the male. To test this hypothesis a detailed study of spermatophore transfer and content in polyandrous and monandrous $P$. archon females is needed.

In $L$. dispar, as in many other moths, mating generally induced a suppression of calling behaviour and a decrease in pheromone production (Tang et al., 1992; Kingan et al., 1993). Nevertheless, in $P$. archon, the oviposition behavior involved, as the calling behavior described by Ollivier \& Frérot (2006), an extrusion of the ovipositor, and high frequencies of mating attempts by $P$. archon males with unreceptive mated females were observed. This suggests that (i) female pheromone production did not stop after mating, (ii) females had a small amount of pheromone on their bodies, and/or (iii) males respond to visual cues. Detailed studies of the pheromone titers of mated females and courtship behaviour are needed to test these hypotheses. Whether males mate more than once was not investigated here; nevertheless, as males that had mated previously did attempt to copulate again the expectation is that they do mate more than once, as in most Lepidoptera (Rutowski, 1982).

In many polyandrous Lepidoptera, females re-mate after ovipositing (Rutowski, 1982). This was not observed in $P$. archon. Indeed, after mating, the laying of the first egg occurs rapidly, even on 3 of 12 females $(25 \%)$ the same day as they mated and females continue to lay eggs throughout their life. This observation is consistent with the here reported observations of female monandry. The maximum delay between mating and laying of the first egg in $P$. archon was not longer than 4 days.

Our results indicate that adults of $P$. archon, which do not feed, generally mate a few hours after emergence and the 
females are mostly monandrous and begin laying eggs 1.25 ( \pm 1.14) days after mating. This reproductive strategy is similar to that recorded for other pest moths, such as: L. dispar, Plodia interpunctella (Hübner) (Pyralidae) and Chillo partellus (Swinhoe) (Pyralidae) (Ramaswamy et al., 1997). The outdoor experimental conditions provided seem to meet the reproductive requirements of $P$. archon, as $100 \%$ of the pairs copulated and a high proportion of females were fertile $(87 \%)$. The results of this study provide the necessary background knowledge for future studies on sex pheromone-mediated behaviour and oviposition in $P$. archon.

ACKNOWLEDGEMENTS. We thank the municipal government of Montpellier and several private individuals, for providing biological material, and CSIRO Montpellier for allowing us to use their laboratory. Financial support was provided by the "Region Languedoc-Roussillon", CIRAD and the "GDR on Chemical Ecology" (G2827, CNRS/INEE).

\section{REFERENCES}

Callahan P.S. 1958: Behavior of the imago of the corn earworm Heliothis zea (Boddie) with special reference to emergence and reproduction. Ann. Entomol. Soc. Am. 51: 271-283.

CARDÉ R.T. \& MinKS A.K. 1995: Control of moth pests by mating disruption: successes and constraints. Annu. Rev. Entomol. 40: 559-585.

Coffelt J.A., Sower L.L. \& VICK K.W. 1978: Quantitative analysis of identified compounds in pheromone gland rinses of Plodia interpunctella and Ephestia cautella at different times of day. Environ. Entomol. 7: 502-505.

Cusson M. \& McNeIL J.N. 1989: Ovarian development in female armyworm moths Pseudaletia unipuncta: its relationship with pheromone release activities. Can. J. Zool. 6: $1380-1385$.

Danilevsky A.S., Goryshin N.I. \& Tyschenko V.P. 1970: Biological rhythms in terrestrial arthropods. Annu. Rev. Entomol. 15: 201-244.

Delisle J. \& Royer L. 1994: Changes in pheromone titer of oblique-banded leafroller, Choristoneura rosaceana, virgin females as a function of time of day, age and temperature. $J$. Chem. Ecol. 20: 45-69.

Dresher J. \& JAUBert R. 2003: Paysandisia archon continue sa progression. PHM Rev. Horticole 445: 49-51.

FATZINGER C.W. 1973: Circadian rhythmicity of sex pheromone release by Dioryctria abietella (Lepidoptera: Pyralidae (Phycitinae)) and the effect of a diel light cycle on its precopulatory behavior. Ann. Entomol. Soc. Am. 66: 1147-1153.

FATZINGER C.W. \& AsHeR W.C. 1971: Mating behavior and evidence for a sex pheromone of Dioryctria abietella (Lepidoptera: Pyralidae (Phycitinae)). Ann. Entomol. Soc. Am. 64: $612-620$.

Gemeno C. \& Haynes K.F. 2000: Periodical and age-related variation in chemical communication system of black cutworm moth Agrotis ipsilon. J. Chem. Ecol. 26: 329-342.

Giebultowicz J.M., Raina A.K., Uebel E.C. \& Ridgway R.L. 1991: Two-step regulation of sex pheromone decline in mated gypsy moth females. Arch. Insect Biochem. Physiol. 16: 95-105.

Hunt R.E. \& Haynes K.F. 1990: Periodicity in the quantity and blend ratios of pheromone components in glands and volatile emissions of mutant and normal cabbage looper moths Trichoplusia ni. J. Insect Physiol. 36: 769-774.
Kingan T.G., Thomas-Laemon P.A. \& Raina A.K. 1993: Male accessory gland factors elicit change from "virgin" to "mated" behavior in the female corn earworm moth Helicoverpa zea. J. Exp. Biol. 183: 61-76.

LAMAS G. 1995: A critical review of J.Y. Miller's checklist of the neotropical Castniidae (Lepidoptera). Revta Peruana Entomol. 37: 73-87.

Miller J.Y. 1995: Castniidae. In Heppner J.B. (ed.): Atlas of Neotropical Lepidoptera. Checklist: Part 2. Association for Tropical Lepidoptera, Scientific Publishers, Gainesville, FL pp. 133-137, 176-177.

Ollivier L. \& FréRot B. 2006: Paysandisia archon, vous avez dit phéromone? Phytoma 594: 30-32.

Pope M.M., Gaston L.K. \& BaKer T.C. 1982: Composition quantification and periodicity of sex pheromone gland volatiles from individual Heliothis virescens females. J. Chem. Ecol. 8: 1043-1055.

Proshold F.I. \& Bernon G.L. 1994: Multiple mating in laboratory-reared Gypsy moths (Lepidoptera: Lymantriidae). J. Econ. Entomol. 87: 661-666.

R Development Core Team 2010: $R$ : A Language and Environment for Statistical Computing. R Foundation for Statistical Computing, Vienna, Austria. ISBN 3-900051-07-0, URL http://www.R-project.org/.

Raina A.K., Klun J.A. \& Stadelbacher E.A. 1986: Diel Periodicity and effect of age and mating on female sex pheromone titer in Heliothis zea (Lepidoptera: Noctuidae). Ann. Entomol. Soc. Am. 79: 128-131.

Raina A.K., Davis J.C. \& Stadelbacher E.A. 1991: Sex pheromone production and calling in Helicoverpa zea (Lepidoptera: Noctuidae): Effect of temperature and light. Environ. Entomol. 20: 1451-1456.

Ramaswamy S.B., Shu S., Park Y.I. \& Zeng F. 1997: Dynamics of juvenile hormone-mediated gonadotropism in the Lepidoptera. Arch. Insect Biochem. Physiol. 35: 539-558.

Rutowski R.L. 1982: Mate choice and lepidopteran mating behavior. Fla Entomol. 65: 72-82.

Sarto I Monteys V. \& Aguilar L. 2005: The Castniid palm borer Paysandisia archon (Burmeister 1880) in Europe: comparative biology pest status and possible control methods (Lepidoptera: Castniidae). Nach. Entomol. Ver. Apollo N.F. 26(1/2): 61-94.

SHOREY H.H. \& GASTON L.K. 1965: Sex pheromones of noctuid moths. V. Circadian rhythm of pheromone responsiveness in males of Autographa californica, Heliothis virescens, Spodoptera exigua and Trichoplusia ni (Lepidoptera: Noctuidae). Ann. Entomol. Soc. Am. 58: 597-600.

Sower L.L., Shorey H.H. \& Gaston L.K. 1971: Sex pheromones of noctuid moths. XXV. Effects of temperature and photoperiod on circadian rhythms of sex pheromone release by females of Trichoplusia ni. Ann. Entomol. Soc. Am. 64: 488-492.

Tang J.D., Charlton R.E., Cardé R.T. \& Yin C.-M. 1992: Diel periodicity and influence of age and mating on sex pheromone titer in Gyspy moth Lymantria dispar (L.). J. Chem. Ecol. 18: 749-760.

TRAYNiER R.M.M. 1970: Sexual behaviour of the Mediterranean flour moth Anagasta kühniella: some influences of age photoperiod and light intensity. Can. Entomol. 102: 534-540.

Turgeon J. \& McNeIL J. 1982: Calling behaviour of the armyworm Pseudaletia unipuncta. Entomol. Exp. Appl. 31: 402-408.

Received August 26, 2011; revised and accepted January 25, 2012 